\title{
EFFICIENCY OF BIOLOGICAL PREPARATIONS AND MICROELELMENTS IN THE TECHNOLOGY OF SPRING WHEAT CULTIVATION
}

${ }^{1}$ Derevyanskyy V. P., ${ }^{1}$ Vlasyuk O. S., ${ }^{2}$ Malinovska I. M.

${ }^{1}$ Khmelnytsky State Agricultural Experimental Station

Institute of feed research and agriculture of Podillya NAAS,

1, Samchyky Str., Samchyky, Starokostyantynivsky region, Khmelnytsky region, 31182,

Ukraine

E-mail: vchsekretar-hdsgds@yandex.ru

${ }^{2} \mathrm{NSC}$ "Institute of Agriculture" NAAS,

2B, Mashynobudivnykiv Str., Chabany, Kiev region, Ukraine

The paper presents the study of treatment efficiency of seeds and vegetative plants of spring wheat with biological preparations and complex of microelements. Compositions that reduce the disease spreading and improve crop productivity were discovered.

Keywords: spring wheat, inoculation, microelements.

Insufficient agriculture resource supply and environmental crisis stipulate an urgent need to develop technological solutions that would allow mobilization of natural processes affecting plant growth and ensuring stability of agricultural systems, reduction the chemical load on agrocenoses and increase of their productive capacity. One of these solutions is application of a new generation of biological preparations that have complex positive impact on the development of plant-bacterial associations, nitrogen fixation and phosphorous mobilization processes and contribute to the formation of plant resistance to diseases [1-3]. In this context, the relevance of search and application for biological methods of production process intensification is of a big importance.

The aim of given study was to investigate the influence of seeds and plants treatment with complex microbial preparations and microelements on performance in the forest-steppe zone of western Ukraine.

Materials and methods. The experiments were performed in field conditions during the 2006-2008 in temporary rotation of Khmelnytsky SAES NAAS. Besides the biological factors, affecting the realization of productive potential of spring wheat plants, the action of herbicides, alone and in combination with biological preparations was studied.

Scheme of the experiment:

I) Factor "A" - protection against weeds:

1. Soil herbicide Racer, 2.0 1/ha at pre-sowing cultivation;

2. Postemergence herbicide Dialen Super, 0.7 1/ha.

II) Factor "B" - presowing seeds bacterization:

1. No treatment (control);

2. Agrobacterium radiobacter.

III) Factor "C" - plants treatment:

1. No spraying (control);

2. Hetomik; 
3. Ecolyst for grain crops;

4. Hetomik + Ecolyst for grain crops.

The total area of the experimental plot was 100 sq.m, used for calculations -72 sq.m. Experiment replication - three fold, with systematic plot placement. Cultivar of spring wheat - Collectivna 3.

Research field soils - podzolized chernozem, middle loam, slightly washed. Agrochemical characteristics of topsoil: $\mathrm{pH}$ saline - 5.5-6.0; humus by Tyurin - 3.2-3.6; nitrogen easily hydrolyzed $-12-17 \mathrm{mg}$ per $100 \mathrm{~g}$; movable phosphorus - 13-18.5, metabolic potassium - 10.0-11.1 mg per $100 \mathrm{~g}$ of soil.

Spring wheat was sowed in field rotation preceded by - sugar beets with typical to the western forest-steppe region farming. Tillage consisted of shallow ploughing after fore crop and subsequent plowing with surface alignment with early spring mulching. Mineral fertilizers were applied during pre-sowing cultivation at dose $\mathrm{N}_{32} \mathrm{P}_{32} \mathrm{~K}_{32}$. Seeding rate for spring wheat -6000000 seeds per 1 ha.

Seeds and vegetative plants were treated according to the experiment scheme. Agrobacterium radiobacter 10 (provided by ASRIAM, St. Petersburg, Russia) was used for seeds bacterization. The total bacterial load was 200 thousand cells per seed.

Hetomik - preparation based on micromycete Chaetomium cochliodes 3250, with high antagonistic activity to a wide range of pathogenic fungi (developer - Institute for Agricultural Microbiology and Agricultural Production NAAS). Application rate $200 \mathrm{~g} / \mathrm{ha}[4]$.

Ecolyst for grain crops - chelated complex of microelements (chelation agent EDTA). Application rate was according to manufacturer's recommendations $-41 /$ ha.

Climate and weather conditions in 2006-2010 were favorable for the cultivation of spring wheat. The average air temperature during the growing season (May-September) in 2006 was $18.5^{\circ} \mathrm{C}, 2007-18.7^{\circ} \mathrm{C}, 2008-18.8^{\circ} \mathrm{C}, 2009-19.2^{\circ} \mathrm{C}, 2010-19.6^{\circ} \mathrm{C}$. Total rainfall for May - September 2006 was $-695 \mathrm{~mm}$, in $2007-769.4 \mathrm{~mm}$, in $2008-$ $655.6 \mathrm{~mm}$, in $2009-475 \mathrm{~mm}$ and in $2010-976.6 \mathrm{~mm}$.

Experiment record and observations were carried out by standard methods $[5,6]$.

Results and discussion. Weather conditions during 2006-2010 growing period were favorable for the development and spread of spring wheat diseases. Observation of crop infection with diseases have revealed positive influence of complex treatment application resulting in decrease of diseases development. Thus, level of wheat leaf blotch infection on experimental plants (presowing seeds and vegetative plants treatment with biopreparations and microelements on the background of soil herbicide Racer) have decreased on $10.2-13.6 \%$ as comparing to control. In other variants, the disease development was significantly higher.

Application of biological preparations have revealed their effect against on root rots. Thus the disease spreading was lower $(7.3 \%)$ in variants with presowing seeds bacterization with Agrobacterium radiobacter (on the background of soil herbicide Racer), whereas in control (no seeds treatment) $12,1 \%$ of plants were infected.

Weediness of spring wheat crops is one of the factors that reduces wheat productivity the most. In 2006-2010 selectivity to spring wheat and phytotoxic effects on the weed species composition by soil herbicide Racer and postemergence herbicide Dialen Super were studied. Most clearly the herbicidal activity of investigated preparations and 
their application methods were observed by the weeds mass accumulation index. Records, performed prior to the harvest have showed that application of soil herbicide Racer has not inferior to the action on weeds of postemergence herbicide.

Wet spring of 2007 and 2008 have promoted rise of herbicidal activity of soil preparation Racer. Its application has reduced the total number of weeds on 93-96\%. Herbicidal activity of Dialen Super against dicotyledonous weeds was 92-95 \%.

Observations of spring wheat crops density performed at stage of full sprouting and before harvesting indicate that soil herbicide Racer $(2.0 \mathrm{l} / \mathrm{ha}$ ) have not significantly reduced the crops density. Postemergence herbicide have shown its high crop selectivity and have not affected crops density.

Structural analysis have showed that spring wheat plants were higher in variants with seeds and crops treated with microbial preparations and microelements $(85-101 \mathrm{~cm})$, whereas in the control (without treatments) on the background of postemergence herbicide $-76.6 \mathrm{~cm}$

Analysis of yield records for 2006-2010 have confirmed the effectiveness of integrated application of herbicides, microbial preparations and foliage application (Table $1)$.

TABLE 1. Effect of herbicides and biological preparations on yield of spring wheat (2006-2010)

\begin{tabular}{|l|c|c|c|c|c|c|c|c|}
\hline \multirow{2}{*}{ Variants } & \multicolumn{5}{|c|}{ Yield, c/ha } & \multicolumn{2}{c|}{$\begin{array}{c}\text { Increment } \\
\text { to control }\end{array}$} \\
\cline { 2 - 9 } & 2006 & 2007 & 2008 & 2009 & 2010 & Mean & c/ha & $\%$ \\
\hline \multicolumn{1}{|c}{1} & 2 & 3 & 4 & 5 & 6 & 7 & 8 & 9 \\
\hline $\begin{array}{l}\text { Background 1. } \\
\text { Soil herbicide Racer }\end{array}$ & 34,2 & 21,4 & 35,8 & 32,6 & 30,4 & 30,9 & - & - \\
\hline $\begin{array}{l}\text { Background 1+ seeds } \\
\text { treatment with } \\
\text { Agrobacterium radiobacter }\end{array}$ & 38,2 & 23,9 & 37,6 & 33,5 & 31,9 & 33,0 & 2,1 & 6,4 \\
\hline $\begin{array}{l}\text { Background I crops } \\
\text { treatment with Hetomik }\end{array}$ & 36,3 & 22,8 & 36,4 & 32,9 & 31,3 & 31,9 & 1,0 & 3,1 \\
\hline $\begin{array}{l}\text { Background I seeds treat- } \\
\text { ment with Agrobacterium } \\
\text { radiobacter + crops } \\
\text { treatment with Hetomik }\end{array}$ & 39,8 & 24,8 & 39,2 & 37,9 & 33,5 & 35,0 & 4,1 & 11,7 \\
\hline $\begin{array}{l}\text { Background I +rops } \\
\text { treatment with Ekolist for } \\
\text { grain crops }\end{array}$ & 36,2 & 22,7 & 38,4 & 33,3 & 31,8 & 32,5 & 1,6 & 4,9 \\
\hline $\begin{array}{l}\text { Background I + seeds } \\
\text { treatment with } \\
\begin{array}{l}\text { Agrobacterium radiobacter }+ \\
\text { crops treatment with Ekolist }\end{array}\end{array}$ & 38,4 & 22,9 & 39,1 & 34,4 & 32,5 & 33,5 & 2,6 & 7,8 \\
\hline $\begin{array}{l}\text { Background I + crops } \\
\text { treatment with Hetomik and } \\
\text { Ekolist }\end{array}$ & 37,4 & 23,6 & 39,7 & 33,0 & 32,7 & 33,3 & 2,4 & 7,2 \\
\hline
\end{tabular}


TABLE CONTINUED 1.

\begin{tabular}{|c|c|c|c|c|c|c|c|c|}
\hline 1 & 2 & 3 & 4 & 5 & 6 & 7 & 8 & 9 \\
\hline $\begin{array}{l}\text { Background I + seeds } \\
\text { treatment with } \\
\text { Agrobacterium radiobacter }+ \\
\text { crops treatment with } \\
\text { Hetomik + Ekolist }\end{array}$ & 40,9 & 24,9 & 40,8 & 38,1 & 34,8 & 35,9 & 5,0 & 13,9 \\
\hline $\begin{array}{l}\text { Background 2. Applicatioon } \\
\text { of postemergence herbicide } \\
\text { Dialen Super }\end{array}$ & 33,7 & 22,7 & 34,1 & 33,4 & 30,6 & 30,9 & 0 & 0 \\
\hline $\begin{array}{l}\text { Background } 2+\text { seeds } \\
\text { treatment with } \\
\text { Agrobacterium radiobacter }\end{array}$ & 37,1 & 24,3 & 37,2 & 32,9 & 31,8 & 32,7 & 1,8 & 5,5 \\
\hline $\begin{array}{l}\text { Background } 2+\text { crops } \\
\text { treatment with Hetomik }\end{array}$ & 37,0 & 23,5 & 37,1 & 32,8 & 31,9 & 32,5 & 1,6 & 4,9 \\
\hline $\begin{array}{l}\text { Background } 2 \\
\text { Agrobacterium radiobacter }+ \\
\text { crops treatment with } \\
\text { Hetomik }\end{array}$ & 37,2 & 25,9 & 38,0 & 36,0 & 33,3 & 34,1 & 3,2 & 9,4 \\
\hline $\begin{array}{l}\text { Background } 2+\text { crops } \\
\text { treatment with Ekolistom } \\
\text { зерновим }\end{array}$ & 36,0 & 22,5 & 37,6 & 34,0 & 31,7 & 32,3 & 1,4 & 4,3 \\
\hline $\begin{array}{l}\text { Background } 2+\text { seeds } \\
\text { treatment with } \\
\text { Agrobacterium radiobacter }+ \\
\text { crops treatment with Ekolist }\end{array}$ & 37,9 & 22,8 & 37,8 & 37,3 & 33,7 & 33,9 & 3,0 & 8,8 \\
\hline $\begin{array}{l}\text { Background } 2+\text { crops } \\
\text { treatment with Hetomik }+ \\
\text { Ekolist }\end{array}$ & 35,7 & 25,1 & 38,2 & 34,4 & 32,7 & 33,2 & 2,3 & 6,9 \\
\hline $\begin{array}{l}\text { Background } 2+\text { seeds } \\
\text { treatment with } \\
\text { Agrobacterium radiobacter }+ \\
\text { crops treatment with } \\
\text { Hetomik ta Ekolistom }\end{array}$ & 39,2 & 27,6 & 40,1 & 36,3 & 34,5 & 35,5 & 4,6 & 12,9 \\
\hline $\begin{array}{r}\mathrm{HIP}_{0,5}: \quad \begin{array}{l}\mathrm{A}-\text { seeds } \\
\text { treatment }\end{array} \\
\mathrm{B}-\text { crops treatment } \\
\mathrm{C}-\text { interaction } \\
\mathrm{AB}- \\
\mathrm{AC}- \\
\mathrm{BC}- \\
\mathrm{P}, \%\end{array}$ & $\begin{array}{l}0,27 \\
0,29 \\
0,33 \\
0,54 \\
0,54 \\
0,79 \\
0,30\end{array}$ & $\begin{array}{l}0,35 \\
0,40 \\
0,42 \\
0,60 \\
0,60 \\
0,85 \\
0,35\end{array}$ & $\begin{array}{l}0,18 \\
0,26 \\
0,26 \\
0,37 \\
0,37 \\
0,74 \\
0,12\end{array}$ & $\begin{array}{l}0,19 \\
0,27 \\
0,27 \\
0,38 \\
0,38 \\
0,54 \\
0,14\end{array}$ & $\begin{array}{l}0,26 \\
0,26 \\
0,18 \\
0,52 \\
0,37 \\
0,37 \\
0,14\end{array}$ & & & \\
\hline
\end{tabular}


Yield analysis have also shown that treatment of seeds and crops with microbial preparations in combination with foliar application of Ecolyst for grain crops on a background of soil herbicide Racer is the most efficient among the presented experiment options.

The quality of grain have differ under the influence of preparations used and weather conditions. Thus, more gluten in wheat spring grains was observed in variants with seeds and crops treatment with Agrobacterium radiobacter + Hetomik + Ecolyst on the background with Dialen Super $-25.6 \%$, while in control $(\mathrm{C} / 2)$, without treatment (excluding herbicide) $-24.2 \%$.

Introduction of soil herbicide Racer (2.0 1/ha) accompanied by seeds treatment with Agrobacterium radiobacter and subsequent crops treatment with Hetomik and Ecolyst for cereal crops into the technology of spring wheat cultivation can increase crops yield by $5.0 \mathrm{c} /$ ha or $14.1 \%$. Moreover, given combination reduces the cost of production, following by profit increase per 1 centner of output and improvement of profitability.

Thus, it was established that microbial seeds inoculation with microbial preparations combined with crops treatment with Hetomik and followed by foliar application of micronutrients can reduce spring wheat crops infection with root rots and leaf blotch. Complex treatment of seeds and vegetative plants with microbial preparations and microelements stimulates the development of vegetative and generative organs of plants, increases the content of gluten in spring wheat and ensures productivity increase by 15 $19 \%$.

Energy cost of herbicides, preparations and microelements are $20-22 \%$ of the total cost of cultivation, but at the expense of a significant increase in productivity they will compensated 5-6 times. 